\title{
Performance Measurement of Palm Sugar Business using the Integration of Supply Chain Operation Reference (SCOR) and Objective Matrix (OMAX)
}

\author{
Adelia Caroline ${ }^{1}$, Makkarennu $^{1 *}$, Syahidah $^{1}$ \\ *Faculty of Forestry, Hasanuddin University, Jl. Perintis Kemerdekaan Km. 10 Tamalanrea, Makassar, \\ Sulawesi Selatan, Indonesia
}

\begin{abstract}
Arenga pinnata is one of non-timber forest products (NTFPs) commodities that have high economic value. This tree is one of the multipurpose commodities because almost all parts of the tree can be utilized. The people around the forest have a lot of palm sugar as one of their livelihood sources. However, supply chain management of palm sugar businesses has not been integrated from the supply of raw materials, the production process, distribution and marketing pf the product. Measurement of Palm Sugar Supply Chain Performance is conducted to measure the performance of supply chain of palm sugar and formulate the recommendations on indicators that are still below target. The research was located in Bonto Sinala village, Sinjai Regency, South Sulawesi, Indonesia. Data collection methods through interviews using a questionnaire in the palm sugar farmer group. Data analysis was carried out by implementing the Supply Chain Operation Reference model using the Analytical Hierarchy Process (AHP) and Objective Matrix (OMAX) model. The result study of measurement the supply chain performance using Supply Chain Operation Reference (SCOR) method found in 24 KPI with 4 KPI for plan variables, 4 KPI for source variables, $10 \mathrm{KPI}$ for make variables, $3 \mathrm{KPI}$ for deliver variables and 3 KPI for return variables. The overall supply chain performance value is 6.62 with 17 KPI that included in the green category, 3 KPI that included in the yellow category, and 4 KPI that included in the red category. KPI that included in the yellow and red categories must be corrected immediately.
\end{abstract}

Keywords: Supply chain, palm sugar, SCOR, OMAX

\section{INTRODUCTION}

Non-Timber Forest Products (NTPs) are all goods or materials taken from the forest other than wood which are used for household needs or marketed [1]. NTFPs management can fulfill various livelihood functions and provide consumptive goods directly [2]. NTFPs are used for economic activities and community welfare in an effort to change the course of forest management [3]. In addition, it is also increase food security and increase the income on people's livelihoods [4]. Palm sugar is one of the NTFPs commodities that has high economic value and one of livelihood sources on rural communities ources [5]. The use of sugar palm trees can be done in almost all parts of the tree like for medicines and handicrafts. Moreover, sugar palm has the greatest economic value [6]. Palm sugar has many advantages compared to sugar cane, because it has a more diverse nutritional content, has antioxidant properties, low glycemic index, and good benefits for health [7].

Palm sugar business is a business that involves various parties, including farmers as a producers and raw material supply who play a role in providing assurance regarding the availability of raw materials which are distributed to collectors or selling directly to processing raw materials for brown sugar [8]. Business optimization that involves cooperation ranging from raw material supply, raw material processing, manufacturing and consumers. This activity is integrated with a management system supply chain [ 9] [10] revealed that supply chain is a network consisting of several business actors in which there is a flow of products, information and finance. System setup supply chain can be done through mutually beneficial cooperation that ensures sustainability and increases the overall optimization of activities [11].

The problem faced in managing the palm sugar business in Sinjai Regency is the weak capacity of the community in the commercialization of the palm sugar produced, this because of the low quality of the product. [12] [13] there are supporting factors in the value chain system, especially food products, one of these factors is product quality [14]. In addition, the palm sugar products are only marketed to traditional markets due to the low 
quality of the product and the lack of community capacity in implementing marketing strategies and business development. Moreover, supply chain management not yet integrated from upstream to downstream. Supply chain management integrated from upstream to downstream can improve competitiveness [15]. Supply chain management is the integration between the activities of procuring raw materials and services, converting them into semi-finished goods and final products as well as delivering products to customers.

To determine the right business development strategy, it is necessary to analyze the performance of each supply chain by applying the model Supply Chain Operation Reference using method Analytical Hierarchy Process (AHP).

The Performance achievement score on palm sugar supply chain business that is obtained were revealed which indicators the achievement is still below the target, so that corrective action can be taken to be able to produce products that can compete in the market.

\section{Methods}

\section{A. Study Site}

The research was located in Bonto Sinala Village, Sinjai Borong District, Sinjai Regency. According to data from the Sinjai Central Statistics Agency (2018), the potential for sugar palm trees in Sinjai Regency is 25886 trees with the large in size is 209.41 ha. Palm trees are scattered in six sub-districts namely West Sinjai, Central Sinjai, South Sinjai, Tellulimpoe, Bulupoddo, and Sinjai Borong Districts. The number of family heads who make the palm sugar business a livelihood is 628 .

\section{B. Data Collection Technique}

The research stages are carried out through direct observation of the activities of providing raw materials and processing palm sugar. Interviews with stakeholders involved in palm sugar processing using a questionnaire. Stakeholders involved include village head, land owner (palm tree owner) as many as 10 people, palm sugar farmer-producers (head and members of farmer groups) as many as 40 people, traders ( 2 people) and consumers (10 people). The questionnaire used is a closed questionnaire in which the respondents only answer the questionnaire that has been determined to answer each element of the SCOR process. Literature study was also carried out by collecting secondary data that supports this research. This research used quantitative methods with a descriptive approach. The population in this study were palm sugar farmer-producers in the Bonto Sinala Village, Sinjai Borong District, Sinjai Regency. In this study, the sample used is the technique purposive sampling, where the determination of the sample for certain considerations. Each subject taken from the population was chosen deliberately with the aim and consideration that the respondent had been making palm sugar for a long time and had adequate information in fulfilling data needs.

\section{Data Analysis}

The analysis data used SCOR (supply chain operation reference) integrated with AHP (Analytical Hierarchy Process) and OMAX (Objective Matrix). Model SCOR were used with multiple adjustments for key performance indicators or KPIs for the five elements of the process (plan, source, make, deliver and return). Weighting using AHP through pairwise comparisons between perspectives in general and comparison of each KPI (Key Performance Indicators) used to measure supply chain performance and scoring system using the Objective Matrix (OMAX). Weighting is done to provide a score of performance achievement and to find out which indicators the achievement is still below the target. Each indicator is presented using Traffic Light System by using green, yellow and red. Green indicates that the achievement of a performance indicator has been achieved. Yellow indicates the achievement of a performance indicator has not been achieved even though the value is close to the target and red indicates that the achievement of a performance indicator is really below the predetermined target and requires immediate improvement.

\section{III.RESULTS}

\section{A. Supply Chain of palm Sugar Business}

The supply chain showed the relationship between the supplier and the consumer. The Supply chain actors in the palm sugar business consist of tappers (farmer), producers, collectors, intermediary traders and consumers (Figure 1). 


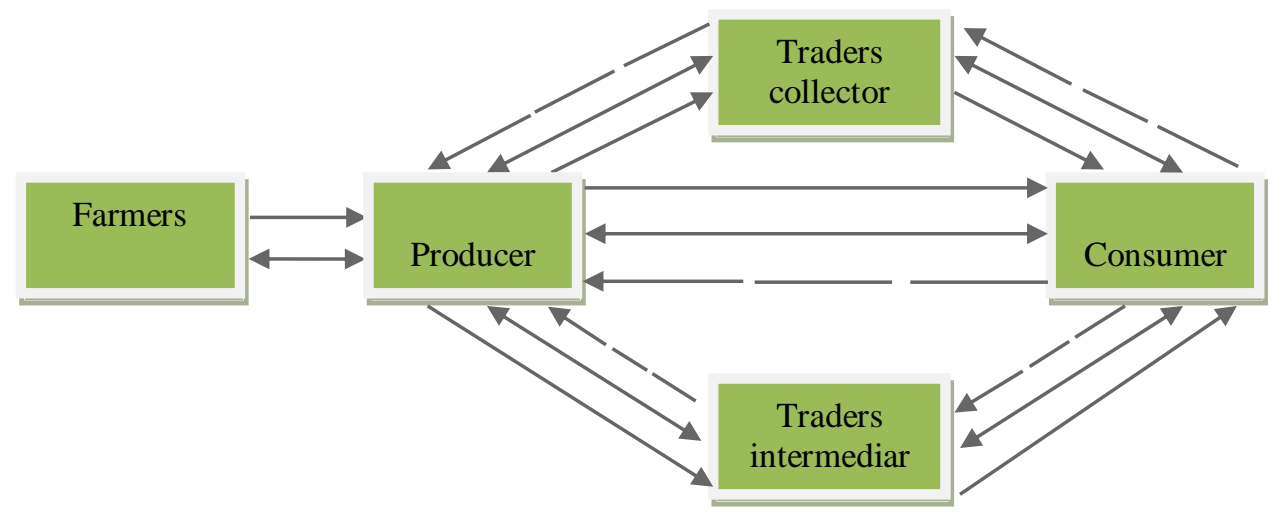

Figure 1. Supply chain for palm sugar business

Where: $\longrightarrow$ The flow of goods movement

$\longleftrightarrow$ The flow of information movement

$\longrightarrow$ The flow of money movement

The picture above showed that the supply chain for palm sugar business in Bonto Sinala Village, Sinjai Borong District, Sinjai Regency is still simple, where the supply chain does not involve many business actors. Tappers take the raw material for sap using a ladder made of bamboo. The tapped palm trees are harvested in the morning and evening, then the raw materials are directly transported to the palm sugar production house. Palm sugar is made traditionally, starting with cooking the sap using a frying pan which is cooked for 8 hours using wood as fuel and formed using coconut shells. Next, the palm sugar that has been formed then wrapped using corn leaves and brown leaves. Collectors and intermediary traders have a trusting relationship with producers, where traders order palm sugar products first and then buy them. Structuring the supply chain system can be done through mutually beneficial cooperation that ensures sustainability and increases the optimality of all activities [11], this is in line with the supply chain in the palm sugar business where there is cooperation between traders and producers of palm sugar.

\section{B. Consistency Test of Core Variables}

Consistency test is conducted to test the consistency of comparison between criteria and the entire hierarchy against the 5 elements of the process (plan, source, make, deliver and return) with the KPI. If the value of CR $\leq$ 0.1 means, the assessment of weight criteria is accepted. The consistency test of core variables can be seen in Table 1.

Table 1. Consistency Test of Core Variables

\begin{tabular}{|c|c|}
\hline Perspective & Weight \\
\hline Plan & 0.485 \\
\hline Source & 0.122 \\
\hline Make & 0.259 \\
\hline Deliver & 0.076 \\
\hline Return & 0.059 \\
\hline Total & 1 \\
\hline CR & 0.1 \\
\hline
\end{tabular}

The table above shows the weight value of the core variable. The highest weight value is obtained on the plan variable of 0.485 and the lowest weight is obtained by the return variable. All these variables have a consistency ratio of 0.1 then the entire weight of the value was consistent. 


\section{Dimensional consistency tests}

Dimensional consistency tests are carried out on each dimension that is in the core variable. The dimension consists of reliability, responsiveness and flexibility. The consistency test results for each dimension can be seen in Table 2.

Table 2. Dimensional consistency tests

\begin{tabular}{|l|l|l|}
\hline Core variables & Dimensions & Weight \\
\hline \multirow{4}{*}{ Source } & Reliability & 0.750 \\
\cline { 2 - 3 } & Responsivness & 0.250 \\
\cline { 2 - 3 } & Total & 1 \\
\cline { 2 - 3 } & CR & 0 \\
\hline \multirow{4}{*}{ Make } & Reliability & 0.537 \\
\cline { 2 - 3 } & Responsivness & 0.268 \\
\cline { 2 - 3 } & Flexibility & 0.195 \\
\cline { 2 - 3 } & Total & 1 \\
\cline { 2 - 3 } & CR & 0.09 \\
\hline \multirow{5}{*}{ Return } & Reliability & 0.800 \\
\cline { 2 - 3 } & Responsivness & 0.200 \\
\cline { 2 - 3 } & Total & 1.00 \\
\cline { 2 - 3 } & CR & 0.00 \\
\hline
\end{tabular}

The table above shows the results of the consistency test of each dimension in the core variable. On the source variable, the highest weight value is obtained on the reliability dimension was 0.750 and the lowest weight on the responsiveness dimension which is 0.250 . All dimensions have a consistency ratio of 0 which indicates that the weights were consistent. The make variable has 3 dimensions with the highest weight value obtained on the reliability dimension was 0.537 and the lowest weight on the flexibility dimension which is 0.195. All dimensions have a consistency ratio of 0.090 that indicates the weights were consistent. On return Variables the highest weight value is obtained on the dimension reliability i.e., 0.800 and the lowest weight on the dimension responsivness which is 0.200 . All dimensions have a consistency ratio of 0,00 which indicates that the weights were consistent.

\section{KPI Weighting}

Weighting is done for each KPI. KPI can be used to predict the chances of success or failure from the processes that implemented by the organization [16]. In every performance measurement process, a measure is needed to determine the level of success or achievement of the company's performance. One of the measures used in the performance measurement process is the main performance indicator or Key Performance Indicator (KPI). The results of the KPI weighting can be seen in Table 3.

Table 3. KPI's Weighting

\begin{tabular}{|c|c|c|c|c|}
\hline Core variables & Dimensions & KPI's & Weight & CR \\
\hline \multirow{4}{*}{ Plan } & \multirow{4}{*}{ Reliability } & KPI 1 & 0.273 & \multirow{4}{*}{0.1} \\
\hline & & KPI 2 & 0.169 & \\
\hline & & KPI 3 & 0.463 & \\
\hline & & KPI 4 & 0.096 & \\
\hline \multirow{4}{*}{ Source } & \multirow{3}{*}{ Reliability } & KPI 5 & 0.121 & \multirow{4}{*}{0} \\
\hline & & KPI 6 & 0.417 & \\
\hline & & KPI 7 & 0.269 & \\
\hline & Responsivness & KPI 8 & 0.193 & \\
\hline \multirow{2}{*}{ Make } & \multirow{2}{*}{ Reliability } & KPI 9 & 0.149 & \multirow{2}{*}{0.1} \\
\hline & & KPI 10 & 0.242 & \\
\hline
\end{tabular}




\begin{tabular}{|c|c|c|c|c|}
\hline & & KPI 11 & 0.162 & \\
\hline & & KPI 12 & 0.110 & \\
\hline & & KPI 13 & 0.095 & \\
\hline & & KPI 14 & 0.066 & \\
\hline & \multirow{3}{*}{ Responsivness } & KPI 15 & 0.051 & \\
\hline & & KPI 16 & 0.037 & \\
\hline & & KPI 17 & 0.058 & \\
\hline & Flexibility & KPI 18 & 0.032 & \\
\hline \multirow{3}{*}{ Deliver } & \multirow{3}{*}{ Responsivness } & KPI 19 & 0.537 & \multirow{3}{*}{0.1} \\
\hline & & KPI 20 & 0.268 & \\
\hline & & KPI 21 & 0.195 & \\
\hline \multirow{3}{*}{ Return } & Responsivness & KPI 22 & 0.334 & \multirow{3}{*}{0.05} \\
\hline & \multirow{2}{*}{ Flexibility } & KPI 23 & 0.525 & \\
\hline & & KPI 24 & 0.142 & \\
\hline
\end{tabular}

The table above shows the weighting results for each KPI. On the plan variable, the highest weight is found in KPI 3 with a weight value was 0.463 . KPI which has the highest weight value on the source variable contained in KPI 6 with a weighted value was 0.417 . KPI which has the highest weight value on make variable showed in KPI 10 with a weighted value was 0.242 . KPI which has the highest weight value on the deliver variable contained in KPI 19 with a weighted value was 0.537 and KPI which has the highest weight value on return variable contained in KPI 23 a value weight was 0.525 . All KPI have a consistency ratio of $<0.1$, thus indicating that the weights are consistent.

\section{E. Scoring System}

Scoring system is done using objective matrix. The results of this scoring system showed the value of scoring system for each plan, source, make, deliver and return variable. Result of scoring system on plan variable can be seen in Table 4.

Table 4. Scoring System Plan variable

\begin{tabular}{|c|c|c|c|c|c|}
\hline \multicolumn{2}{|c|}{ KPI } & $\mathrm{P} 1$ & $\mathrm{P} 2$ & P3 & $\mathrm{P} 4$ \\
\hline \multicolumn{2}{|c|}{ Performance } & 81.67 & 75.00 & 73.33 & 30.00 \\
\hline \multirow{11}{*}{$\sum_{\pi}^{T}$} & 10 & 92.78 & 86.11 & 95.56 & 63.33 \\
\hline & 9 & 83.57 & 77.38 & 85.36 & 54.64 \\
\hline & 8 & 74.37 & 68.65 & 75.16 & 45.95 \\
\hline & 7 & 65.16 & 59.92 & 64.96 & 37.26 \\
\hline & 6 & 55.95 & 51.19 & 54.76 & 28.57 \\
\hline & 5 & 46.75 & 42.46 & 44.56 & 19.88 \\
\hline & 4 & 37.54 & 33.73 & 34.37 & 11.19 \\
\hline & 3 & 28.33 & 25.00 & 24.17 & 2.50 \\
\hline & 2 & 23.61 & 20.83 & 20.14 & 2.08 \\
\hline & 1 & 18.89 & 16.67 & 16.11 & 1.67 \\
\hline & 0 & 14.17 & 12.50 & 12.08 & 1.25 \\
\hline \multicolumn{2}{|c|}{ Level } & 8.79 & 8.73 & 7.82 & 6.16 \\
\hline \multicolumn{2}{|c|}{ Weight } & 0.27 & 0.17 & 0.46 & 0.10 \\
\hline \multicolumn{2}{|c|}{ Value } & 2.40 & 1.47 & 3.62 & 0.59 \\
\hline
\end{tabular}


The table above gives information the value scoring of plan variable system. The highest scoring system value is KPI 1 with score achievement was 8.79. This achievement score has passed the target with traffic light system is green color which indicates that the performance indicator has been reached. The lowest scoring system value is KPI 4 with score achievement was 6.16. This achievement score has not reached the target with traffic light system is yellow color which indicates that a performance indicator has not been achieved even though the value is close to the target so that it needs to be improved. Result of scoring system on source variables can be seen in Table 5.

Table 5. Scoring System Source Variable

\begin{tabular}{|l|l|l|l|l|l|}
\hline \multicolumn{2}{|l|}{ KPI } & S5 & S6 & S7 & S8 \\
\hline \multicolumn{2}{|c|}{ Performance } & 70.00 & 71.67 & 78.33 & 80.00 \\
\hline \multirow{4}{*}{ T. } & 10 & 92.22 & 93.89 & 89.44 & 91.11 \\
\cline { 2 - 6 } & 9 & 82.26 & 83.81 & 80.48 & 82.02 \\
\cline { 2 - 6 } & 8 & 72.30 & 73.73 & 71.51 & 72.94 \\
\cline { 2 - 6 } & 7 & 62.34 & 63.65 & 62.54 & 63.85 \\
\hline & 6 & 52.38 & 53.57 & 53.57 & 54.76 \\
\cline { 2 - 6 } & 5 & 42.42 & 43.49 & 44.60 & 45.67 \\
\hline & 4 & 32.46 & 33.41 & 35.63 & 36.59 \\
\hline & 3 & 22.50 & 23.33 & 26.67 & 27.50 \\
\hline & 2 & 18.75 & 19.44 & 22.22 & 22.92 \\
\hline Level & 1 & 15.00 & 11.67 & 17.78 & 18.33 \\
\hline Weight & 0 & 11.25 & 11.67 & 13.33 & 13.75 \\
\hline Value & 7.77 & 7.80 & 8.76 & 8.78 \\
\hline
\end{tabular}

Table 5 shows the value of the scoring system of variable source. The highest scoring system value is KPI 8 with score achievement was 8.78. The lowest scoring system value is KPI 5 with score an achievement was 7.77. Result of scoring system on source variables already crossed the target with traffic light system green color which indicates that a performance indicator has been reached. Result of scoring system on variables source can be seen in Table 6 .

Table 6. Scoring System Make Variabel

\begin{tabular}{|c|c|c|c|c|c|c|c|c|c|c|c|}
\hline \multicolumn{2}{|c|}{ KPI } & M9 & M10 & M11 & M12 & M13 & M14 & M15 & M16 & M17 & M18 \\
\hline \multicolumn{2}{|c|}{ Performance } & 81.67 & 76.67 & 85.00 & 80.00 & 71.67 & 70.00 & 48.33 & 46.67 & 76.67 & 78.33 \\
\hline \multirow{11}{*}{$\begin{array}{l}\text { 莺 } \\
\text { 祭 }\end{array}$} & 10 & 92.78 & 87.78 & 96.11 & 91.11 & 93.89 & 92.22 & 70.56 & 68.89 & 87.78 & 89.44 \\
\hline & 9 & 83.57 & 78.93 & 86.67 & 82.02 & 83.81 & 82.98 & 62.86 & 61.31 & 78.93 & 80.48 \\
\hline & 8 & 74.37 & 70.08 & 77.22 & 72.94 & 73.73 & 73.73 & 55.16 & 53.73 & 70.08 & 71.51 \\
\hline & 7 & 65.16 & 61.23 & 67.78 & 63.85 & 63.65 & 64.48 & 47.46 & 46.15 & 61.23 & 62.54 \\
\hline & 6 & 55.95 & 52.38 & 58.33 & 54.76 & 53.57 & 55.24 & 39.76 & 38.57 & 52.38 & 53.57 \\
\hline & 5 & 46.75 & 43.53 & 48.89 & 45.67 & 43.49 & 45.99 & 32.06 & 30.99 & 43.53 & 44.60 \\
\hline & 4 & 37.54 & 34.68 & 39.44 & 36.59 & 33.41 & 36.75 & 24.37 & 23.41 & 34.68 & 35.63 \\
\hline & 3 & 28.33 & 25.83 & 30.00 & 27.50 & 23.33 & 27.50 & 16.67 & 15.83 & 25.83 & 26.67 \\
\hline & 2 & 23.61 & 21.53 & 25.00 & 22.92 & 19.44 & 22.08 & 13.06 & 12.36 & 21.53 & 22.22 \\
\hline & 1 & 18.89 & 17.22 & 20.00 & 18.33 & 15.56 & 16.67 & 9.44 & 8.89 & 17.22 & 17.78 \\
\hline & 0 & 14.17 & 12.92 & 15.00 & 13.75 & 11.67 & 11.25 & 5.83 & 5.42 & 12.92 & 13.33 \\
\hline \multicolumn{2}{|c|}{ Level } & 8.79 & 8.74 & 8.82 & 8.78 & 7.80 & 7.60 & 7.11 & 7.07 & 8.74 & 8.76 \\
\hline
\end{tabular}




\begin{tabular}{|l|c|c|c|c|c|c|c|c|c|c|}
\hline Weight & 0.15 & 0.24 & 0.16 & 0.11 & 0.10 & 0.07 & 0.05 & 0.04 & 0.06 & 0.03 \\
\hline Value & 1.31 & 2.12 & 1.43 & 0.96 & 0.74 & 0.50 & 0.36 & 0.26 & 0.50 & 0.28 \\
\hline
\end{tabular}

Table 6 shows the scoring value of the make variable system. The highest scoring system value is KPI 11 with score an achievement was 8.82. This achievement score has passed the target with traffic light system green color which indicates that a performance indicator has been reached. The lowest scoring system value is KPI 16 with score achievement was 7.07. this score achievement has not reached the target with traffic light system yellow color which indicates that a performance indicator has not been achieved even though the value has approached the target so that it needs to be corrected. Result of scoring system on variables deliver can be seen in Table 7

Table 7. Scoring System Deliver Variabel

\begin{tabular}{|c|c|c|c|c|}
\hline \multicolumn{2}{|c|}{ KPI } & D19 & D20 & D21 \\
\hline \multicolumn{2}{|c|}{ Performance } & 66.7 & 60 & 16.7 \\
\hline \multirow{11}{*}{$\sum_{\pi}^{m}$} & 10 & 88.89 & 82.22 & 50.00 \\
\hline & 9 & 79.17 & 72.98 & 45.95 \\
\hline & 8 & 69.44 & 63.73 & 41.90 \\
\hline & 7 & 59.72 & 54.48 & 37.86 \\
\hline & 6 & 50.00 & 45.24 & 33.81 \\
\hline & 5 & 40.28 & 35.99 & 29.76 \\
\hline & 4 & 30.56 & 26.75 & 25.71 \\
\hline & 3 & 20.83 & 17.50 & 21.67 \\
\hline & 2 & 17.36 & 14.58 & 18.06 \\
\hline & 1 & 13.89 & 11.67 & 14.44 \\
\hline & 0 & 10.42 & 8.75 & 10.83 \\
\hline \multicolumn{2}{|c|}{ Level } & 7.71 & 7.60 & 1.62 \\
\hline \multicolumn{2}{|c|}{ Weight } & 0.537 & 0.268 & 0.195 \\
\hline \multicolumn{2}{|c|}{ Value } & 4.15 & 2.04 & 0.31 \\
\hline
\end{tabular}

Table 7 shows the value of the variable scoring system of deliver. The highest scoring system value is KPI 19 with score an achievement was 7.71. The achievement has passed the target with traffic light system green color which indicates that a performance indicator has been reached. The lowest scoring system value is KPI 21 with score achievement was 1.62. this achievement score has not reached the target with traffic light system colored red which indicates that a performance indicator is lowermost the target and needs immediate repair. Result of scoring system on variables deliver can be seen in Table 8 .

Table 8. Scoring System Return Variabel

\begin{tabular}{|l|l|l|l|l|}
\hline \multicolumn{2}{|l|}{ KPI } & R22 & R23 & R24 \\
\hline \multicolumn{2}{|c|}{ Performance } & 16.67 & 13.33 & 11.67 \\
\hline \multirow{3}{*}{3} & 10 & 50.00 & 46.67 & 45.00 \\
\cline { 2 - 5 } & 9 & 45.95 & 42.62 & 40.95 \\
\cline { 2 - 5 } & 8 & 41.90 & 38.57 & 36.90 \\
\hline & 7 & 37.86 & 34.52 & 32.86 \\
\cline { 2 - 5 } & 6 & 33.81 & 30.48 & 28.81 \\
\cline { 2 - 5 } & 5 & 29.76 & 26.43 & 24.76 \\
\hline & 4 & 25.71 & 22.38 & 20.71 \\
\hline & 3 & 21.67 & 18.33 & 16.67 \\
\hline
\end{tabular}




\begin{tabular}{|l|l|l|l|l|} 
& 1 & 14.44 & 12.22 & 11.11 \\
\hline & 0 & 10.83 & 9.17 & 8.33 \\
\hline Level & & 1.62 & 1.36 & 1.20 \\
\hline Weight & 0.33 & 0.52 & 0.14 \\
\hline Value & 0.54 & 0.72 & 0.17 \\
\hline
\end{tabular}

The table above shows the scoring value of the return variable. Value scoring system on variables return have traffic light system colored red which indicates that a performance indicator is lower most the target and needs to improve. Overall, the measurement performance results of supply chain can be seen in Table 9.

Table 9. Measurement Performance Results of Palm Sugar Supply

\begin{tabular}{|c|c|c|c|}
\hline No & Variables & Dimensions & KPI \\
\hline 1 & \multirow{4}{*}{ Plan (7.88) } & \multirow{4}{*}{ reliability (7.88) } & KPI 1 (8.79) \\
\hline 2 & & & KPI 2 (8.73) \\
\hline 3 & & & KPI 3 (7.82) \\
\hline 4 & & & KPI 4 (6.16) \\
\hline 5 & \multirow{4}{*}{ Source (8.44) } & \multirow{3}{*}{ reliability $(8.10)$} & KPI 5 (7.77) \\
\hline 6 & & & KPI 6 (7.80) \\
\hline 7 & & & KPI 7 (8.76) \\
\hline 8 & & responsivness (8.78) & KPI 8 (8.78) \\
\hline 9 & \multirow{10}{*}{ Make (8.27) } & \multirow{6}{*}{ reliability (8.42) } & KPI 9 (8.79) \\
\hline 10 & & & KPI 10 (8.74) \\
\hline 11 & & & KPI 11 (8.82) \\
\hline 12 & & & KPI $12(8.78)$ \\
\hline 13 & & & KPI $13(7.80)$ \\
\hline 14 & & & KPI $14(7.60)$ \\
\hline 15 & & \multirow{3}{*}{ responsivness (7.64) } & KPI 15 (7.11) \\
\hline 16 & & & KPI $16(7.07)$ \\
\hline 17 & & & KPI 17 (8.74) \\
\hline 18 & & flexibility (8.76) & KPI 18 (8.76) \\
\hline 19 & \multirow{3}{*}{ Deliver (5.64) } & \multirow{3}{*}{ responsivness (5.64) } & KPI 19 (7.71) \\
\hline 20 & & & KPI $20(7.60)$ \\
\hline 21 & & & KPI 21 (1.62) \\
\hline 22 & \multirow{3}{*}{ Return (2.90) } & responsivness (1.62) & KPI 22 (1.62) \\
\hline 23 & & \multirow{2}{*}{ flexibility (1.28) } & KPI 23 (1.36) \\
\hline 24 & & & KPI $24(1.20)$ \\
\hline \multicolumn{4}{|c|}{ Index Total } \\
\hline & & 6.62 & \\
\hline
\end{tabular}

Table 9 indicate that the overall palm sugar supply chain performance with a yellow traffic light system (6.62) which indicates that a performance indicator has not been achieved even though the value is already 
approaching the target. KPI 4 with indicator internal relations between workers in terms of the needs of raw materials need to be improve. KPI 15 is the addition of production costs if at any time there are obstacles in production. KPI 16 is a process cost change on handling the production process when raw materials are damaged. KPI 21 is a shipping costs change due to certain obstacles. KPI 22, namely complaints from consumers regarding the quality of goods. KPI 23 is an entrepreneur's response in replacing damaged products. KPI 24 is the condition of goods that do not suit the standard when returned.

\section{IV.CONCLUSIONS}

Based on the calculation of the scoring system that has been done, it can be seen that there are 17 KPI included in the green category, 3 KPI included in the Yellow category, and 4 KPI that included in the red category. The KPI go into the yellow and red category must be implemented immediately so that the implementation of Supply Chain does not decrease. This condition will lead to a bad influence on the production activities that take place. KPI that needs to be immediately obtained an action to repairs consists of KPI 4 (the fulfillment of production raw materials), KPI 15 and 16 addition of costs and changes in costs during production), KPI 21 (changes in costs during the product delivery process) and KPI 22 23, 24 (returns the goods that are not in accordance with the standard).

Here are some recommendations or improvements the palm sugar business (in yellow performance indicators):

1. Fulfillment of production raw materials

The fulfillment of production raw materials can be overcome by planting palm trees every year. Planting of palm trees conducted every year will increase reserves of palm trees that can be managed continuously. Kutim dwarf sugar palm or aren genjah in local name can be used as an alternative in the region. Dwarp type produces a sap at the age of 5-6 years.

2. Adding costs and changes in costs during production.

Addition of costs and changes in costs when production can be overcome by replacing fuel in the form of wood using energy-saving furnaces. The addition of costs occurs when the cooking is on progress and the fuel in the form of wood that using has not been able to overcome the need to produce the sugar. The availability of firewood in the area is rare so that farmers must buy wood to be used as fuel.

Recommendations of improvements that can be made by farmer groups who carry out the processing of palm sugar based on the results of the traffic light system on red performance indicators:

1. Change costs at the time of delivery

Changes in cost when shipping can be overcome by selecting shipping services that are suitable for customer wishes. The shipping services available today already have information about the estimated arrival of goods or products sent.

2. Return of Products

Returns Products consist of customer complaints, employers' responses and conditions of goods that are not in accordance with standards. This condition can be overcome by providing complaint channels for customers so that the employers can make improvements to any complaints entered.

\section{REFERENCES}

[1] Waluyo KT. 2013. Rencana dan progres penelitian pengolahan HHBK lingkup Badan Litbang Kehutanan. Prosiding Seminar Nasional HHBK. Peranan Hasil Litbang Hasil Hutan Bukan Kayu dalam Mendukung Pembangunan Kehutanan. 12 September 2012, Mataram. Pusat Penelitian dan Pengembangan Peningkatan Produktivitas Hutan. Badan Penelitian dan Pengembangan Kehutanan, Kementerian Kehutanan, Bogor. 20-26.

[2] Shackleton, C. M. 2015. Non-timber forest products in livelihoods. Pages 12-30 in C. M. Shackleton, A. K. Pandey, and T. Ticktin, editors. The ecological sustainability for non-timber forest products: dynamics and case studies of harvesting. Earthscan, London, UK

[3] Torres-Rojo, J. M., Moreno-Sánchez, R., Martín, \&, \& Mendoza-Briseño, A. (2016). Sustainable Forest Management in Mexico. Curr Forestry Rep, 2, 93- 105

[4] Matthew C, Alex Z, Mariano G, Felly T, Mark M, Monica N, Peter A, Madeleine N. 2018. Geographic factors predict wild food and nonfood NTFP collection by households across four African countries. Forest Policy and Economics. (96: 38-53

[5] Suhesti \& Hadinoto. "Hasil Hutan Bukan Kayu Madu Salang di Kabupaten Kampar (Studi Kasus: Kecamatan Kampar Kiri Tengah)". Wahana Forestra 10(2): 16-26, 2015.

[6] Murtado, Utami, S. T., \& Theresia, E. M. 2014. Aren (Arenga pinnata): Investasi Menarik Belum Dilirik. Pusat Penyuluhan Kehutanan, Badan Penyuluhan dan Pengembangan SDM Kehutanan, Kementerian Kehutanan.

[7] Heriyani, H. 2016. Keutamaan Gula Aren \& Strategi Pengembangan Produk. Lambung Mangkurat University Press. Banjarmasin. 
[8] Ikhwana A, Y Mauluddin, E J Hayat, D S Taptajani and M I Suandi. 2019. Supply chain support factors for brown sugar business optimality using analytical hierarchy process. J. Phys.: Conf. Ser. 1402022037

[9] Monczka R M, Handfield R B, Giunipero L C and Patterson J L 2015 Purchasing and supply chain management (Cengage Learning)

[10] Sari, P. N., \& Nurmalina, R. "Manajemen Rantai Pasok Pada Rantai Pasok Berjaring Beras Organik". Forum Agribisnis: Agribusiness Forum, 3(2), 111-128, 2013.

[11] Ikhwana A. "Analisis Dan Strategi Penambahan Nilai Jual Komoditas Kopi Melalui Penataan Rantai Nilai Komoditas Kopi ". J. Kalibr. 15 1-8, 2017.

[12] Swinnen J. "Some dynamic aspects of food standards Am". J. Agric. Econ. 99 321-38, 2017.

[13] Makkarennu, Supratman, Yumeina., Caroline, A. "Integrated supply chain management and SCOR model: A strategic approach for small sized business". International Joirnal of Science and Management Studies. 3(3): 1-11

[14] Diallo C, Venkatadri U, Khatab A and Bhakthavatchalam S. "State of the art review of quality, reliability and maintenance issues in closed-loop supply chains with remanufacturing”. Int. J. Prod. Res. 55 1277-96, 2017.

[15] Tunggal. A. W. 2009. Akuntansi Manajemen. Jakarta : Harvindo

[16] Parmenter, David. 2010. Key Performance Indicator, Gramedia, Jakarta.

[17] Laksananny, S. A, Pijirahayu, N. "Analisis Kelayakan Usahatani Tanaman Aren (Arenga pinnata merr) Genjah pada Sistem Agroforestri Di Kawasan Tahura Nipa-Nipa Kendari “. Jurnal Ecogreen. 3(1) : 33-39, 2017. 